\title{
Barkhausen Noise Emission in Case - Hardened Bearing Steels
}

Miroslav Neslušan ${ }^{1}$, Róbert Farda ${ }^{1}$, Kamil Kolařík ${ }^{2}$, Jiří Čapek ${ }^{2}$

${ }^{1 Z ̌ U}$ Žilina, Univerzitná 1, 01026 Žilina, KOVT, SjF, E-mail: miroslav.neslusan@fstroj.uniza.sk,

${ }^{2}$ ČVUT Praha, Trojanova 13, 120 00, Praha 2, ČR

This paper deals with detection of surface burn after grinding operations on bearing rings made of case - hardened steels. The paper reports about Barkhausen noise technique employed for non destructive monitoring of grinding burn and discusses the main aspects affecting the Barkhausen noise emission such as thickness of heat affected zone, micro hardness, stress state, carbides, dislocation density and volume of retained austenite. Results of experiments indicate that the influence of stress state on Barkhausen noise is only minor whereas influence of structure features dominates. On the other hand, it is difficult to unwrap influence microstructure features contribution to the Barkhausen noise. For this reason their influence should be studied on the model surfaces undergoing the different regime of chemical and heat treatment.

Keywords: grinding burn, Barkhausen noise, bearings

\section{Acknowledgment}

This article was edited under the financial support of KEGA projects $n .005 \check{U} U$ - 4/2014 and 009ŽU - 4/2014.

\section{References}

[1] BARKHAUSEN, H. (1919). Phys. Zeitschrift, 20, pp. 201.

[2] MOORTHY, V. et all. (2007). Assessment of Depth Grinding Damage on Gear Teeth using Magnetic Barkhausen Noise Measurement, ICBN 06, Valenciennes, France.

[3] SORSA, A. et all. (2012). Quantitative prediction of residual stresses and hardness in case-hardened steel based on the Barkhausen noise measurement, NDT\&E Int.Vol.46, pp. 100-106.

[4] ABUKU, S., CULliTY, R.D. (1971). A Magnetic Method for Determination of Residual Stress, Exp. Mech.,11.

[5] VASHISTA, M., PAUL, S. (2009). Correlation between Surface integrity of Ground Medium Carbon Steel with Barkhausen Noise Parameters and Magnetic Hysteresis Loop Characteristics, Materials and Design Vol. 30, pp. 1595-1603.

[6] NESLUŠAN, M., ROSIPAL M., OCHODEK, V. (2011). Analysis of some Aspects of Surface Integrity after Grinding and Hard Turning trough Barkhausen Noise, ICBN 09, Hejnice, Czech Republic.

[7] ČILLIKOVÁ, M. et all. (2013). Non-destructive micromagnetic evaluation of surface damage after grinding, Manufacturing Technology, Vol.13/2, pp. 152-157.

[8] BATISTA, I., RABE, U., HIRSEKORN, S. (2013). Magnetic micro- and nanostructures of unalloyed steels: Domain wall interactions with cementite precipitates observed by MFM, NDT\&E Int. Vol. 57, pp. 58-68.

[9] RANJAN, R., et all. (1987). Magnetic properties of decarburized steels: An investigation of the effects of grain size and carbon content, NDT\&E Int. Vol.23/3, pp.1869-1876.

[10]BUTTLE, D.J. et all. (1994). Magneto-acoustic and Barkhausen emission: their dependence on dislocations in iron, NDT \& E Int. Vol.24, pp. 47-54.

[11]HAJKO, V., POTOCKÝ, L., ZENTKO, A. (1982). Magnetization processes, ALFA Bratislava. 